\title{
Performance and methane emissions of Nellore steers grazing tropical pasture supplemented with lipid sources
}

\author{
Isabela Pena Carvalho de Carvalho', Giovani Fiorentini ${ }^{1}$, Alexandre Berndt' ${ }^{2}$, Pablo de Souza \\ Castagnino1, Juliana Duarte Messana', Rosa Toyoko Shiraishi Frighetto ${ }^{3}$, Ricardo Andrade \\ Reis $^{1,4}$, Telma Teresinha Berchielli ${ }^{1,4}$
}

\author{
${ }^{1}$ Universidade Estadual Paulista, Faculdade de Ciências Agrárias e Veterinárias, Jaboticabal, SP, Brazil. \\ ${ }^{2}$ Embrapa Pecuária Sudeste, São Carlos, SP, Brazil. \\ ${ }^{3}$ Embrapa Meio Ambiente, Jaguariúna, SP, Brazil. \\ ${ }^{4}$ Researcher CNPq/Member of INCT-CA.
}

\begin{abstract}
The objective of this study was to evaluate the effect of lipid sources on voluntary intake, digestibility, performance, and $\mathrm{CH}_{4}$ emission of Nellore steers grazing Brachiaria brizantha cv. Xaraés forage in the dry season. Forty-five Nellore steers with average weight of $442 \pm 34 \mathrm{~kg}$ were alloted into one of the five treatments: without additional fat; with palm oil; with linseed oil; with protected fat; and with whole soybeans. The supplements were provided daily and quantities were adjusted to $1 \%$ of body weight and diets were formulated in accordance with the Cornell Net Carbohydrate and Protein System. The experimental design was completely randomized with five treatments and two replications. There were no effects on dry matter, organic matter, and neutral detergent fiber intake with the inclusion of lipids in the diet. The neutral detergent fiber showed decreased digestibility in animals receiving linseed oil and palm oil treatments compared with animals receiving the diet without additional fat. The linseed oil treatment reduced $\mathrm{CH}_{4}$ emissions by $38 \%$ when expressed in $\mathrm{mg} / \mathrm{d} / \mathrm{kg} \mathrm{BW}$ and tended to reduce the emission in $\mathrm{g} / \mathrm{d} / \mathrm{kg} \mathrm{BW}^{0.75}$. Lipid sources did not affect the weight gain of the animals. The intake and performance of grazing Nellore steers supplemented at $1 \%$ body weight with lipid sources were not modified. However, fiber digestibility was reduced with palm or linseed oil addition. Linseed oil reduced enteric $\mathrm{CH}_{4}$ emissions. Linseed oil has the potential to reduce enteric $\mathrm{CH}_{4}$ emissions in continuous tropical grazing systems based on $B$. brizantha grass.
\end{abstract}

Key Words: linseed oil, palm oil, protected fat, supplementation, whole soybeans

\section{Introduction}

The production of beef cattle in tropical countries is generally associated with grazing cultivated pastures and low production costs. However, increased competitions in feed prices for better meat quality as well as the growing concern about emissions of greenhouse gases are causing changes in the beef production system in Brazil and in the world.

Methane $\left(\mathrm{CH}_{4}\right)$ and $\mathrm{CO}_{2}$ are natural byproducts of microbial fermentation of carbohydrates and, to a lesser extent, aminoacids in the rumen and the hindgut of farm animals (Hristov et al., 2013). Methane emissions represent a loss of about 5 to $7 \%$ of dietary gross energy (to as low as

Received February 11, 2016 and accepted August 4, 2016.

Corresponding author: giovanizoot@yahoo.com.br

http://dx.doi.org/10.1590/S1806-92902016001200005

Copyright (C) 2016 Sociedade Brasileira de Zootecnia. This is an Open Access article distributed under the terms of the Creative Commons Attribution License (http://creativecommons.org/licenses/by/4.0/), which permits unrestricted use, distribution, and reproduction in any medium, provided the original work is properly cited.
$3 \%$ in cattle fed high-grain diets) and are about 16 to $26 \mathrm{~g} / \mathrm{kg}$ of dietary dry matter intake (DMI) (could be lower with diets containing very high proportions of grain) (Hristov et al., 2013). Various strategies can be used to reduce enteric $\mathrm{CH}_{4}$ production (Hristov et al., 2013), highlighting the inclusion of dietary lipids (Martin et al., 2010). The addition of lipids to ruminant diets has also been recommended, as it similarly increases energy efficiency and hence reduces methanogenesis. Although greater concentrations of fats substantially decrease methane production, they often exert detrimental effects on fiber digestion and, consequently, on animal performance (Patra, 2013).

Supplementation of unsaturated fatty acids (UFA) exerts deleterious effects on methanogens and protozoa and reduces the acetate:propionate ratio in the rumen (Macmüller et al., 1998). In this manner, there is a reduction in production of ruminal enteric $\mathrm{CH}_{4}$ and the intensity in which this inhibition occurs is determined by the degree of fat saturation and the supplemented amount (Fievez et al., 2003). These disturbances are attributed mainly to modifications in the rumen microbial ecosystem (Doreau and Chilliard, 1997). Although polyunsaturated 
fatty acids (PUFA) may decrease protozoa and promote cellulolysis (Doreau and Ferlay, 1995), the prevailing action is the modification of microbial membrane permeability, causing metabolic disorders, mainly in cellulolytic flora (Maia et al., 2007).

Many products with different fatty acid profiles can be used as fat sources in diets for ruminants (Fiorentini et al., 2014; Neto et al., 2015). However, there are few studies that assess the effect of lipids upon $\mathrm{CH}_{4}$ emission mitigation and upon performance of zebu cattle grazing tropical pasture. Furtheremore, diets rich in fiber could result in increased rates of lipolysis and hydrogenation (Jenkins, 1993) and cause less toxicity to microorganisms due to reduction in the level of dietary PUFA (Broudiscou et al., 1994).

We hypothesized that the inclusion of lipids in supplements for grazing cattle reduces $\mathrm{CH}_{4}$ emissions without affecting performance and that more unsaturated sources would cause greater reductions. In this manner, this work aimed to evaluate intake, digestibility, performance, and emission of enteric $\mathrm{CH}_{4}$ in Nellore steers supplemented with lipid sources and grazing Brachiaria brizantha cv. Xaraés forage during dry season.

\section{Material and Methods}

The study was carried out in Jaboticabal, SP, Brazil, located at $21^{\circ} 15^{\prime} 22^{\prime \prime} \mathrm{S}$ latitude, $48^{\circ} 18^{\prime} 58^{\prime \prime} \mathrm{W}$ longitude and $595 \mathrm{~m}$ altitude. According to the Köppen classification, the climate of Jaboticabal is tropical, Awa type, with rainy summers and dry winters. The protocol used on this experiment was in accordance with the COBEA (Colégio Brasileiro de Experimentação Animal) guidelines and was approved by the CEBEA (Comissão de Ética e Bem Estar Animal) of the FCAV-UNESP - Jaboticabal campus (case no. 012799).

Forty-five castrated Nellore steers with average initial body weight of $442 \pm 34 \mathrm{~kg}$ and eight months of age were used. The animals were kept in 1.9-ha paddocks of Brachiaria brizantha cv. Xaraés pasture under continuous grazing system with a variable stocking rate (put and take), maintaining a sward height of $35 \mathrm{~cm}$. The animals were distributed in a completely randomized design (five animals per paddock and two paddocks per treatment) with two replicates per treatment.

The formulations of diets were specified using RLM/ Esalq-USP software (Lanna etal., 1999) and were formulated for maximum optimization of animal performance. The treatments consisted of supplemental lipid sources in concentrate: without additional fat; with palm oil derived from the palmaceae plant Orbignya oleifera, which has a lipid profile rich in medium-chain fatty acids (lauristic and myristic); with linseed oil; with protected fat (Lactoplus - Dalquim group, Itajaí, Santa Catarina, Brazil); and with whole soybeans. The supplements were provided daily at $1 \%$ of body weight in an open trough at $08.00 \mathrm{~h}$. Supplements were formulated (Table 1) to reach $10 \%$ of ether extract in dry matter of supplement, except for treatment without additional fat, which was $4.1 \%$.

To determine the weight gain, animals were weighed at the beginning and at the end of the experiment and every $28 \mathrm{~d}$ to adjust the amount of supplement provided. Steers were fasted (feed and water) for $14 \mathrm{~h}$, for initial and final weight measurements.

The estimation of individual feed intake was performed by the two-marker method: LIPE $^{\circledR}$ and indigestible acid detergent fiber (iADF), used to estimate the excretion of fecal matter (as dry weight) and forage intake, respectively. Fecal dry matter excretion was determined using purified and enriched lignin $\left(\right.$ LIPE $\left.^{\circledR}\right)$ described by Santos et al. (2011). The animals received the marker daily for six days of the digestion trial. After three days of adaptation, fecal samples were collected daily directly from the rectum, at $16.00,11.00$, and $07.00 \mathrm{~h}$ on the first, second, and third day of collection, respectively. Samples of feces from each animal on each day of collection were individually used to determine the concentrations of LIPE ${ }^{\circledR}$.

The forage intake was estimated based on fecal production data using the $\mathrm{iADF}$ of the forage obtained from

Table 1 - Supplement and pasture compositions ( $\mathrm{g} / \mathrm{kg}$ on a DM basis)

\begin{tabular}{lccccc}
\hline & \multicolumn{5}{c}{ Supplement } \\
\cline { 2 - 6 } & WF & PO & LO & PF & WS \\
\hline Ingredient & & & & & \\
Ground corn & 755 & 655 & 655 & 645 & 570 \\
$\quad$ Soybean meal & 200 & 220 & 220 & 220 & 0.00 \\
Palm oil & 0.00 & 80.0 & 0 & 0.00 & 0.00 \\
Linseed oil & 0.00 & 0.00 & 80.0 & 0.00 & 0.00 \\
Protected fat $^{1}$ & 0.00 & 0.00 & 0.00 & 90.0 & 0.00 \\
Whole soybeans $_{\text {Urea }}$ & 0.00 & 0.00 & 0.00 & 0.00 & 400 \\
Minerals & 15.0 & 15.0 & 10.0 & 10.0 & 0.00 \\
Chemical composition & 30.0 & 30.0 & 30.0 & 30.0 & 30.0 \\
$\quad$ Dry matter, g/kg & & & & & \\
Organic matter, g/kg DM & 880 & 890 & 890 & 890 & 890 \\
Crude protein, g/kg DM & 942 & 942 & 943 & 920 & 937 \\
Ether extract, g/kg DM & 220 & 219 & 214 & 224 & 224 \\
Neutral detergent fiber, g/kg DM & 41.0 & 104 & 94.0 & 97.0 & 116 \\
Lignin, g/kg DM & 126 & 119 & 149 & 118 & 129 \\
\hline & 11.0 & 23.0 & 23.0 & 28.0 & 30.0 \\
\hline
\end{tabular}

WF - without additional fat; PO - palm oil; LO - linseed oil; PF - protect fat; WS - whole soybeans; DM - dry matter.

${ }^{1}$ Lactoplus ${ }^{\circledR}$ (Dalquim group, Itajaí, Santa Catarina, Brazil).

${ }^{2}$ Mineral supplement Bellman, Bellboi (Ca, $160 \mathrm{~g}$; P, $40 \mathrm{~g}$; Mg, $5 \mathrm{~g}$; S, $40 \mathrm{~g}$; Na, 160 g; Cu, 945 mg; Mn, 730 mg; Zn, 3,500 mg; I, 70 mg; Co, 56 mg; Se, 18 mg; F (max), $400 \mathrm{mg}$. 
the simulated grazing on the 41 st day of the trial period. The quantification of fecal iADF on forage and supplement samples was obtained after a 264-h ruminal incubation of samples as described by Casali et al. (2008). Acid detergent fiber analysis was performed with the ANKOM200/220 Fiber Analyzer (ANKOM Technology Corp., Fairport, NY, USA). The supplement intake consisted of the total supplement provided divided by the number of animals per paddock, since there were no observed supplement leftovers in the troughs.

Pasture samples were collected during each period with the hand-plucking technique. Samples of the pasture, concentrates, and feces were oven-dried at $55{ }^{\circ} \mathrm{C}$ for $72 \mathrm{~h}$ and ground in a Wiley mill to pass through a $1-\mathrm{mm}$ screen. Procedures described by the Association of Official Analytical Chemists (AOAC, 1990) were used to determine dry matter (DM; method 934.01) and mineral matter (MM; method 942.05) and to obtain an acid ether extract (EE; method 954.02). Nitrogen was determined using an LECO FP-528 nitrogen analyzer (LECO Corp., St. Joseph, MI, USA).

Content of neutral detergent fiber (NDF) and acid detergent fiber (ADF) were based on the procedures described by Mertens (2002) using the ANKOM200/220 Fiber Analyzer (ANKOM Technology Corp., Fairport, NY, USA). The NDF analyses were performed without sodium sulphite, with alpha amylase and corrected for residual ash. The NDF and ADF were also corrected for residual ash. The acid detergent lignin was determined by solubilization of the cellulose with sulfuric acid according to Van Soest et al. (1991).

The gross energy content of feeds (pasture and concentrate) was determined using an adiabatic bomb calorimeter (PARR Instrument Company 6300, Moline, IL, USA). The acid detergent lignin was determined by solubilization of the cellulose with sulfuric acid according to Van Soest et al. (1991).

To determine the fatty acid composition of feed offerings, a sample of approximately $1 \mathrm{~g}$ was used. The frozen sample was homogenized in $20 \mathrm{~mL}$ of a chloroform and methanol solution (2:1) using a Turrax homogenizer, disintegrator, and emulsifier (Folch et al., 1957). In the next step, the lipid-extracted aliquot was methylated using the protocol of Kramer et al. (1997). Fatty acids were quantified (Table 2) using a GC 2010 gas chromatograph (Shimadzu Corp., Kyoto, Japan) with an SP-2560 capillary column $(100 \mathrm{~m} \times 0.20 \mathrm{~mm}$ i.d. with a $0.02-\mu \mathrm{m}$ film thickness) (Supelco, Bellefonte, PA). The initial temperature was set to $70{ }^{\circ} \mathrm{C}$ for $4 \mathrm{~min}\left(13{ }^{\circ} \mathrm{C} / \mathrm{min}\right)$ until it reached $175^{\circ} \mathrm{C}$ and then held for $27 \mathrm{~min}$. After this, the temperature was increased $4{ }^{\circ} \mathrm{C} / \mathrm{min}$ until it reached $215{ }^{\circ} \mathrm{C}$ and was held there for $31 \mathrm{~min}$. Hydrogen was used as the carrier gas with a flow of $40 \mathrm{~cm}^{3} / \mathrm{s}$.

The apparent digestibility coefficients (DC) of DM, OM, and NDF were determined according to the values obtained for intake, fecal output, and diet and fecal composition, following the equation: $\mathrm{DC}=(\mathrm{NI}-\mathrm{NF}) /(\mathrm{NI} \times 100)$, in which $\mathrm{NI}=$ nutrient intake $(\mathrm{kg})$ and $\mathrm{NF}=$ nutrient in the feces $(\mathrm{kg})$.

To evaluate $\mathrm{CH}_{4}$ emission, 20 animals were chosen (four animals per treatment). The selection criterion was the tameness of the animal and easeness to be handled in the management center (stockyard). Each animal received a pair of $\mathrm{SF}_{6}$ capsules with average emissions of $2.78 \pm 1.18 \mathrm{mg} / \mathrm{d}$ and $610 \mathrm{mg}$ of load for the whole set. The air expelled by the animals was sampled for five consecutive days, for $24 \mathrm{~h}$ per $\mathrm{d}$, from the 78th $\mathrm{d}$ of the experimental period.

The basal concentrations of $\mathrm{SF}_{6}$ and $\mathrm{CH}_{4}$ were determined daily from ambient air samples collected by two air samplers in the experimental paddocks. The direct measurement of ruminal $\mathrm{CH}_{4}$ technique was used, in which $\mathrm{SF}_{6}$ was used as tracer gas according to the methods described by Johnson et al. (1994). The flow of $\mathrm{CH}_{4}$ produced by the animals was calculated in relation to the tracer gas flow $\left(\mathrm{SF}_{6}\right)$ from the permeation rate of the inserted capsule in the rumen, accounting for the baseline concentrations of $\mathrm{CH}_{4}$ and $\mathrm{SF}_{6}$ present in the air:

$$
Q_{C H 4}=Q_{S F 6} *\left(\left[\mathrm{CH}_{4}\right]_{Y}-\left[\mathrm{CH}_{4}\right]_{B}\right) /\left[\mathrm{SF}_{6}\right],
$$

in which $Q_{C H 4}=$ rate of methane emission by the animal; $Q_{S F 6}=$ known rate of $\mathrm{SF}_{6}$ emission; $\left[\mathrm{CH}_{4}\right]_{Y}=$ methane concentration in the air sampler; $\left[\mathrm{CH}_{4}\right]_{B}=$ methane

Table 2 - Fatty acid profile of supplements and pasture

\begin{tabular}{lllllll}
\hline & \multicolumn{6}{c}{ Supplement } \\
\cline { 2 - 6 } & WF & PO & LO & PF & WS & \\
\hline Fatty acid, g/100 g & & & & & & \\
C6:0 (caproic) & 0.00 & 0.11 & 0.00 & 2.70 & 0.00 & 0.00 \\
C8:0 (caprlic) & 0.00 & 0.00 & 0.00 & 0.00 & 0.00 & 0.00 \\
C10:0 (capric) & 0.00 & 2.43 & 0.00 & 0.00 & 0.00 & 0.36 \\
C12:0 (lauric) & 0.00 & 37.6 & 0.10 & 4.91 & 0.00 & 1.86 \\
C14:0 (miristic) & 0.14 & 12.6 & 0.04 & 0.04 & 0.02 & 1.31 \\
C15:0 (pentadecanoic) & 0.00 & 0.00 & 0.00 & 0.00 & 5.87 & 0.00 \\
C16:0 (palmitic) & 10.4 & 8.98 & 7.18 & 2.79 & 2.27 & 30.6 \\
C18:0 (stearic) & 3.68 & 2.21 & 4.41 & 14.8 & 6.21 & 3.63 \\
C18:1 (oleic) & 21.8 & 17.1 & 20.5 & 44.8 & 23.5 & 4.33 \\
C18:2 (linoleic) & 48.9 & 14.9 & 23.0 & 25.8 & 54.4 & 15.1 \\
C18:3 (linolenic) & 4.76 & 1.27 & 41.9 & 1.27 & 5.34 & 36.9 \\
Others & 10.4 & 2.80 & 2.80 & 2.78 & 2.31 & 5.80 \\
Saturated fatty acids & 46.3 & 72.6 & 20.4 & 33.9 & 21.4 & 42.7 \\
Unsaturated fatty acids & 53.6 & 27.4 & 79.6 & 66.1 & 78.5 & 57.3 \\
\hline WF - without additional fat; PO - palm oil; LO - linseed oil; PF - protected fat \\
(Lactoplus ${ }^{\mathbb{\Xi}}$ Dalquim group, Itajaí, Santa Catarina, Brazil); WS - whole soybeans.
\end{tabular}


concentration in the blank; and $\left[\mathrm{SF}_{6}\right]=$ sulfur hexafluoride concentration in the air sampler.

The $\mathrm{CH}_{4}$ and $\mathrm{SF}_{6}$ concentrations were determined by gas chromatography in the laboratories in a HP6890 gas chromatograph equipped with flame ionization detector (FID) at $280{ }^{\circ} \mathrm{C}$, Plot HP-Al/M megabore column $(0.53 \mu \mathrm{m}$, $30 \mathrm{~m}$; for $\mathrm{CH}_{4}$ ), an electron capture detector at $300{ }^{\circ} \mathrm{C}$, and HP-MolSiv megabore column $(0.53 \mathrm{~mm} \times 30 \mathrm{~m} \times 25.0$; for $\mathrm{SF}_{6}$ ), with two loops of $0.5 \mathrm{~cm}^{3}$ attached to two six-way valves. The gas chromatograph oven was kept at $50{ }^{\circ} \mathrm{C}$ during the analysis and heated at $150{ }^{\circ} \mathrm{C}$ for approximately 15 min to clean the column.

Data of intake, digestibility, $\mathrm{CH}_{4}$ measurement, and performance were analyzed in a completely randomized design using the MIXED procedure in SAS (Statistical Analysis System, version 9.0). The least square means were compared using the Tukey test. Differences between treatments were considered significant at $\mathrm{P}<0.05$ and trends were discussed at $\mathrm{P}<0.10$.

For intake, digestibility, and performance, initial body weight was used as a covariate. The statistical model used was:

$$
\mathrm{Y} i j=\mu+\mathrm{T} i+\beta 1+\varepsilon i j \operatorname{\varepsilon ij} \sim \mathrm{iidN}(0, \sigma 2),
$$

in which $\mathrm{Y} i j=$ intake, digestibility, and weight gain from treatment $i$ and paddock $j ; \mu=$ general mean; T $i=$ effect of treatment $i(i=1,2,3,4,5) ; \beta 1=$ covariate for initial body weight (IW); and $\varepsilon i j=$ experimental error $(j=1,2)$.

For enteric $\mathrm{CH}_{4}$ emission, the following statistical model was used:

$$
\mathrm{Y} i j=\mu+\mathrm{T} i+\varepsilon i j \varepsilon i j \sim \operatorname{iidN}(0, \sigma 2),
$$

in which $\mathrm{Y} i j=$ enteric $\mathrm{CH}_{4}$ emission from treatment $i$ and paddock $j ; \mu=$ general mean; T $i=$ effect of treatment $i$ $(i=1,2,3,4,5)$; and $\varepsilon i j=$ experimental error $(j=1,2)$.

For the repeated measures of forage traits, analysis of variance was adopted, using the MIXED procedure and the repeated option in SAS. The model included effects of the treatment, month of evaluation, and the interaction month $\times$ treatment, as described in:

$$
\text { Y } i j k=\mu+\mathrm{T} i+\mathrm{P} j+(\mathrm{TP}) i j+\varepsilon i j k \varepsilon i j k \sim \operatorname{iidN}(0, \sigma 2),
$$

in which Yijk $=$ forage traits from treatment $i$ on period $j$ and paddock $k ; \mu=$ general mean; Ti = effect of treatment $i(i=1,2,3,4,5) ; \mathrm{P} j=$ effect of period $j(j=1,2,3,4)$; (TP) $i j=$ effect of the interaction between treatment $i$ and period $j$; and $\varepsilon i j k=$ experimental error $(k=1,2)$. Different covariance structures of the residuals were tested to determine the structure that best adjusted for each trait. The matrices for each variable were chosen according to the BIC (Bayesian Information Criteria), in which the smallest value of BIC is used as selection criterion.

\section{Results}

The canopy height was kept between 35 and $25 \mathrm{~cm}$, with an average stocking rate of $2.4 \mathrm{AU} / \mathrm{ha}$. During the experimental period, the pasture DM content increased over time $(\mathrm{P}<0.001)$ while the protein content decreased $(\mathrm{P}<0.001)$. The NDF $(\mathrm{P}=0.663)$ and $\mathrm{EE}(\mathrm{P}=0.659)$ contents remained unchanged, whereas the ADF content was higher $(\mathrm{P}<0.001)$ only in August (Table 3). The acid detergent insoluble protein expressed relative to the amount of CP was higher $(\mathrm{P}<0.001)$ in the month of August compared with the other periods.

The total DM intake (DMI) $(\mathrm{P}=0.397)$, forage $\mathrm{DM}$ (FDM) $(\mathrm{P}=0.406), \mathrm{OM}(\mathrm{P}=0.398), \mathrm{CP}(\mathrm{P}=0.174)$, and NDF $(P=0.081)$ were not affected by the inclusion of lipids in the diet. Animals fed palm oil had higher $(\mathrm{P}=0.001)$ intake of saturated fatty acids (SFA). The intake of UFA was higher $(\mathrm{P}=0.001)$ in the treatment with whole soybeans, followed by treatment with linseed oil and with protected fat (Table 4). Animals supplemented with linseed oil had reduced apparent digestibility of DM $(\mathrm{P}=0.024)$ and $\mathrm{OM}$ $(\mathrm{P}=0.027)$ compared with protected fat and whole soybean treatments. The NDF digestibility was negatively affected $(\mathrm{P}=0.002)$ by palm oil and linseed oil (Table 4$)$.

No treatment effects were observed for average daily weight gain $(\mathrm{ADG})(\mathrm{P}=0.797)$ and enteric $\mathrm{CH}_{4}$ emissions, expressed in kilograms of $\mathrm{CH}_{4}$ per year $(\mathrm{kg} /$ year $)(\mathrm{P}=0.217)$, grams of $\mathrm{CH}_{4}$ per day $(\mathrm{g} / \mathrm{d})(\mathrm{P}=0.217)$, grams of $\mathrm{CH}_{4}$ per kilogram of DM intake ( $\mathrm{g} / \mathrm{kg} \mathrm{DMI})(\mathrm{P}=0.161)$, and energy loss as $\mathrm{CH}_{4}(\%$ gross energy intake $)(\mathrm{P}=0.157)$. There was, however, a reduction in $\mathrm{CH}_{4}$ emissions in milligrams of $\mathrm{CH}_{4}$ per day per kilogram of body weight $(\mathrm{mg} / \mathrm{d} / \mathrm{kg} \mathrm{BW})$ $(\mathrm{P}=0.044)$ and a reduction trend of grams of $\mathrm{CH}_{4}$ per day

\begin{tabular}{|c|c|c|c|c|c|c|}
\hline & \multicolumn{4}{|c|}{ Month } & \multirow{2}{*}{ SEM } & \multirow{2}{*}{ P-value } \\
\hline & May $^{1}$ & June $^{2}$ & July $^{3}$ & August $^{4}$ & & \\
\hline \multicolumn{7}{|l|}{ Composition } \\
\hline DM, g/kg & $327 d$ & $426 \mathrm{c}$ & $500 \mathrm{~b}$ & $615 a$ & 12.6 & $<0.001$ \\
\hline $\mathrm{OM}, \mathrm{g} / \mathrm{kg}$ of $\mathrm{DM}$ & $910 \mathrm{a}$ & $908 \mathrm{a}$ & $897 b$ & $897 b$ & 11.3 & $<0.001$ \\
\hline $\mathrm{CP}, \mathrm{g} / \mathrm{kg}$ of $\mathrm{DM}$ & $142 \mathrm{a}$ & $131 b$ & $114 \mathrm{c}$ & $86.6 \mathrm{~d}$ & 1.90 & $<0.001$ \\
\hline $\mathrm{NDF}, \mathrm{g} / \mathrm{kg}$ of DM & 523 & 517 & 507 & 515 & 8.71 & 0.663 \\
\hline $\mathrm{ADF}, \mathrm{g} / \mathrm{kg}$ of $\mathrm{DM}$ & $294 b$ & $293 b$ & $299 b$ & $329 a$ & 3.44 & $<0.001$ \\
\hline Lignin, $\mathrm{g} / \mathrm{kg}$ of DM & $50.2 b$ & $50.7 b$ & $68.4 \mathrm{a}$ & $84.4 \mathrm{a}$ & 3.09 & $<0.001$ \\
\hline $\mathrm{EE}, \mathrm{g} / \mathrm{kg}$ of DM & 32.0 & 36.7 & 37.3 & 29.3 & 3.25 & 0.659 \\
\hline ADIP, $\mathrm{g} / \mathrm{kg}$ of $\mathrm{CP}$ & $118 b$ & $119 b$ & $140 \mathrm{~b}$ & $174 a$ & 6.53 & $<0.001$ \\
\hline \multicolumn{7}{|c|}{$\begin{array}{l}{ }^{1} \text { May } 24 \text { th. } \\
{ }^{2} \text { June } 11 \text { th and } 22 \text { nd. } \\
{ }^{3} \text { July } 9 \text { th and } 27 \text { th. } \\
{ }^{4} \text { August } 19 \text { th. } \\
\text { DM - dry matter; OM - organic matter; CP - crude protein; NDF - neutral detergent } \\
\text { fiber; ADF - acid detergent fiber; EE - ether extract; ADIP - acid detergent insoluble } \\
\text { protein; SEM - standard error of the mean. } \\
\text { Means followed by different letters are significantly different at } \mathrm{P}<0.05 \text { by Tukey's test. }\end{array}$} \\
\hline
\end{tabular}

Table 3 - Chemical composition of available pasture in different months of the year

R. Bras. Zootec., 45(12):760-767, 2016 
per kilogram of metabolic weight $\left(\mathrm{g} / \mathrm{d} / \mathrm{BW}^{0.75}\right)(\mathrm{P}=0.087)$, in which the linseed oil supplement reduced $\mathrm{CH}_{4}$ emissions by $38 \%$ compared with the control treatment (Table 5 ).

\section{Discussion}

Reductions in DMI with inclusion of lipids in the diet are often observed (Bateman II and Jenkins, 1998; Wanapat et al., 2011). This effect is usually due to the interference of fatty acids in fiber digestibility (Jenkins, 1993) and inhibition of appetite due to the increase in serum concentrations of unsaturated fatty acids that activate satiety center receptors in the hypothalamus (Allen, 2000). However, in this experiment, the addition of lipid sources in supplements did not affect the DM and nutrient (OM, CP, and NDF) intakes. These results confirm the observations by Allen (2000), who compiled experiments using lipid sources (oilseeds, unprocessed animal fat, hydrogenated fatty acids and triglycerides, and calcium salts of palm oil) in diets of lactating cows. The author found inconsistent effects on DM intake, in which lipids reduced intake on only a few occasions.

Table 4 - Composition of intake and digestibility of lipid-supplemented feeds consumed by Nellore steers

\begin{tabular}{|c|c|c|c|c|c|c|c|}
\hline & \multicolumn{5}{|c|}{ Supplement } & \multirow{2}{*}{ SEM } & \multirow{2}{*}{ P-value } \\
\hline & WF & $\mathrm{PO}$ & LO & $\mathrm{PF}$ & WS & & \\
\hline \multicolumn{8}{|l|}{ Intake, $\mathrm{kg} / \mathrm{d}$} \\
\hline Total dry matter & 11.5 & 11.6 & 11.0 & 12.0 & 12.8 & 0.57 & 0.394 \\
\hline Forage dry matter & 6.70 & 6.98 & 6.09 & 7.14 & 7.93 & 0.59 & 0.406 \\
\hline Organic matter & 10.5 & 10.7 & 10.1 & 10.9 & 11.8 & 0.52 & 0.398 \\
\hline Crude protein & 1.79 & 1.81 & 1.76 & 2.02 & 1.97 & 0.07 & 0.174 \\
\hline Neutral detergent fiber & 4.59 & 4.54 & 4.38 & 4.74 & 5.38 & 0.17 & 0.081 \\
\hline \multicolumn{8}{|l|}{ Fatty acid intake, $\mathrm{g} / \mathrm{d}$} \\
\hline C6:0 (caproic) & $0.01 \mathrm{~b}$ & $0.81 \mathrm{~b}$ & $0.01 \mathrm{~b}$ & $18.8 \mathrm{a}$ & $0.01 \mathrm{~b}$ & 0.69 & $<0.001$ \\
\hline C10:0 (capric) & $0.07 \mathrm{~b}$ & $18.1 \mathrm{a}$ & $0.03 \mathrm{~b}$ & $0.06 b$ & $0.06 \mathrm{~b}$ & 0.80 & $<0.001$ \\
\hline C12:0 (lauric) & $0.12 b$ & $279 \mathrm{a}$ & $0.64 b$ & $34.2 b$ & $0.11 \mathrm{~b}$ & 12.5 & $<0.001$ \\
\hline C14:0 (myristic) & $0.38 \mathrm{~b}$ & $93.2 \mathrm{a}$ & $0.24 b$ & $0.32 b$ & $0.16 \mathrm{~b}$ & 4.14 & $<0.001$ \\
\hline C15:0 (pentadecanoic) & $0.13 b$ & $0.11 b$ & $0.08 \mathrm{~b}$ & $0.11 b$ & $52.9 \mathrm{a}$ & 1.06 & $<0.001$ \\
\hline $\mathrm{C} 16: 0$ (palmitic) & $26.5 b$ & $67.3 \mathrm{a}$ & $39.2 b$ & $20.1 b$ & $21.0 \mathrm{~b}$ & 4.44 & 0.003 \\
\hline C18:0 (stearic) & $9.31 \mathrm{c}$ & $16.5 \mathrm{c}$ & $23.9 \mathrm{c}$ & $103 a$ & $55.9 \mathrm{~b}$ & 4.27 & $<0.001$ \\
\hline C18:1 n9,c (oleic) & $54.9 \mathrm{c}$ & $127 \mathrm{c}$ & $112 \mathrm{c}$ & $313 \mathrm{a}$ & $212 b$ & 15.4 & $<0.001$ \\
\hline C18:2 n6,c (linoleic) & $122 b$ & $111 b$ & $125 b$ & $180 \mathrm{~b}$ & $489 a$ & 18.7 & $<0.001$ \\
\hline C18:3 n6 (linolenic) & $11.9 \mathrm{~b}$ & $9.48 b$ & $227 \mathrm{a}$ & $8.86 b$ & $48.0 \mathrm{~b}$ & 10.1 & $<0.001$ \\
\hline Saturated fatty acids & $204 b c$ & $485 \mathrm{a}$ & $190 \mathrm{c}$ & $283 b$ & $251 \mathrm{bc}$ & 13.2 & 0.001 \\
\hline Unsaturated fatty acids & $193 c$ & $230 \mathrm{c}$ & $438 b$ & $408 \mathrm{~b}$ & $539 a$ & 13.4 & 0.001 \\
\hline Total intake & $398 b$ & $716 a$ & $629 a$ & $691 \mathrm{a}$ & $790 \mathrm{a}$ & 27.9 & 0.003 \\
\hline \multicolumn{8}{|l|}{ Digestibility, kg/kg } \\
\hline Dry matter & $0.59 \mathrm{ab}$ & $0.59 \mathrm{ab}$ & $0.55 \mathrm{~b}$ & $60.0 \mathrm{a}$ & $0.61 \mathrm{a}$ & 0.008 & 0.024 \\
\hline Organic matter & $0.64 \mathrm{ab}$ & $0.64 \mathrm{ab}$ & $0.60 \mathrm{~b}$ & $0.66 \mathrm{a}$ & $0.66 \mathrm{a}$ & 0.007 & 0.027 \\
\hline Neutral detergent fiber & $0.59 \mathrm{a}$ & $0.46 \mathrm{~b}$ & $0.48 \mathrm{~b}$ & $0.62 \mathrm{a}$ & $0.62 \mathrm{a}$ & 0.01 & 0.002 \\
\hline
\end{tabular}

WF - without additional fat; PO - palm oil; LO - linseed oil; PF - protected fat (Lactoplus ${ }^{\circledR}$ Dalquim group, Itajaí, Santa Catarina, Brazil); WS - whole soybeans. SEM - standard error of the mean.

Means followed by different letters are significantly different at $\mathrm{P}<0.05$ by Tukey's test.

Table 5 - Initial and final weights, average daily weight gain, and methane emissions of Nellore steers on feed supplemented with lipids

\begin{tabular}{|c|c|c|c|c|c|c|c|}
\hline & \multicolumn{5}{|c|}{ Supplement } & \multirow{2}{*}{ SEM } & \multirow{2}{*}{ P-value } \\
\hline & WF & $\mathrm{PO}$ & LO & $\mathrm{PF}$ & WS & & \\
\hline Initial weight, $\mathrm{kg}$ & 440 & 430 & 443 & 450 & 444 & 17.4 & 0.734 \\
\hline $\mathrm{ADG}, \mathrm{kg} / \mathrm{d}$ & 0.59 & 0.57 & 0.65 & 0.58 & 0.59 & 0.05 & 0.797 \\
\hline $\mathrm{CH}_{4}, \mathrm{~kg} /$ year & 41.5 & 41.1 & 25.6 & 37.2 & 30.1 & 4.82 & 0.217 \\
\hline $\mathrm{CH}_{4}, \mathrm{~g} / \mathrm{d}$ & 114 & 112 & 70.2 & 101 & 82.4 & 13.2 & 0.217 \\
\hline $\mathrm{CH}_{4}, \mathrm{~kg} / \mathrm{kg}$ gain & 0.24 & 0.24 & 0.14 & 0.23 & 0.18 & 0.03 & 0.304 \\
\hline $\mathrm{CH}_{4}, \mathrm{~g} / \mathrm{kg} \mathrm{DMI}$ & 9.51 & 9.91 & 7.26 & 8.74 & 6.61 & 0.88 & 0.161 \\
\hline $\mathrm{CH}_{4}, \%$ GEI & 3.39 & 3.36 & 2.48 & 2.89 & 2.27 & 0.31 & 0.157 \\
\hline
\end{tabular}

WF - without additional fat; PO - palm oil; LO - linseed oil; PF - protect fat (Lactoplus ${ }^{\circledR}$ Dalquim group, Itajaí, Santa Catarina, Brazil); WS - whole soybeans; SEM - standard error of the mean; ADG - average daily gain; BW - body weight; $\mathrm{BW}^{0.75}$ - metabolic weight; DMI - dry matter intake; GEI - gross energy intake.

Means followed by different letters are significantly different at $\mathrm{P}<0.05$ by Tukey test. 
The inclusion of fat in the diet of ruminants can interfere with the digestibility of nutrients, especially fiber, as observed in this study for treatments with palm oil and with linseed oil. Fiber digestibility reduction has also been observed in diets with linseed oil by Broudiscou et al. (1994), Martin et al. (2008), and Eugène et al. (2011). The PUFA are more toxic to rumen microorganisms due to the number of double bonds in the structure of fatty acids (Jenkins, 1993). The absence of effects on fiber digestion with addition of other sources rich in UFA (soybean fat and protected fat) can be attributed to the low reactivity of protected fat in the rumen and the rigid outer layer in soybeans (Coppock and Wilks, 1991). The seed coat of grains can hinder the bacterial lipolytic action on triglycerides resulting in reduced release of UFA and lesser effect on ruminal microbiota.

It is expected, therefore, that sources with more SFA profile (palm oil) are less harmful to fiber digestibility and intake (Wanapat et al., 2011). In contrast, this was not observed, since the palm oil treatment reduced the fiber digestibility in a manner similar to a source rich in UFA (linseed oil). The medium-chain fatty acids such as lauric and myristic acids found in high amounts in the palm oil diets may be toxic to the bacteria and methanogenic archaea in the rumen (Soliva et al. 2004a and 2004b); and the dissociation of these acids in bacterial cells has been proposed as a mode of antimicrobial action (Goel et al., 2009). Manso et al. (2006) also observed a negative effect on NDF digestibility with increasing level of palm oil included in diets of sheep.

Lipid inclusion in ruminant diets increases the energy density and can result in better performance (Nelson et al., 2004; Rosa et al., 2013). However, fatty acids can reduce ruminal fermentability and potentially affect the performance of the animal. Thus, it is possible that the reduction in nutrient usage in the rumen caused by addition of lipids may have been compensated by the greater energy density of the diet, resulting in no detectable effect upon performance. Gillis et al. (2004) and Luden et al., (2009) also found no effect of fat addition on beef cattle performance.

The estimated enteric $\mathrm{CH}_{4}$ emission was of $41 \mathrm{~kg} /$ year in the control diet. This value was lower than that reported by IPCC (2006), which estimated an average production of $56 \mathrm{~kg} /$ year in cattle. The $\mathrm{CH}_{4}$ emission was of approximately $10 \mathrm{~g}$ per kilogram of DMI in the diet without additional fat, a lower value than that observed in most studies with beef cattle using the $\mathrm{SF}_{6}$ tracer technique. Neto et al. (2015) showed emission values of $15.8 \mathrm{~g} / \mathrm{kg}$ DMI in Nellore bull in pasture fed supplements containing high or low starch with or without soybean grain. These values are far higher than those found in this study. Barbero et al. (2015) found emission values between 10.8 to $19.5 \mathrm{~g} / \mathrm{kg}$ DMI in accordance with treatment (short height $(15-\mathrm{cm}$ grass grazing), high supplementation ( $0.6 \%$ of BW), or tall height (35-cm grass grazing), without supplementation).

Energy loss as $\mathrm{CH}_{4}$ expressed in percentage of energy consumed was of $2.9 \%$ on average. Cattle $\mathrm{CH}_{4}$ emission represents energy loss of around 6\% in grazing animals and $3.5 \%$ in confined animals (IPCC, 2006). According to the presented results, we can infer that the inclusion of concentrate supplement in grazing animals can reduce energy losses, resulting in an efficiency of energy utilization similar to those observed in confined animals (Fiorentini et al., 2014), corroborating Neto et al. (2015). In the evaluation of energy loss in cattle fed only grass, Kurihara et al. (1999) found a $10.9 \%$ energy loss and Pelve et al. (2012) observed that $\mathrm{CH}_{4}$ emissions from nonlactating cows and heifers fed forage harvested from seminatural heterogeneous forages correspond to an average of $8.9 \%$ of gross energy intake.

The linseed oil treatment decreased emission of $\mathrm{CH}_{4}$ by $38 \%$ compared with the diet without supplemental source of lipid (mg/d/kg BW). This reduction was similar to the 33\% observed by Chung et al. (2011) and higher than the $27 \%$ observed by Martin et al. (2008) and the $18 \%$ observed by Beauchemin et al. (2009), using linseed as a lipid source and corn silage as forage. All diets with lipid sources contained, on average, $34 \mathrm{~g}$ of additional lipid per kilogram of DM and the reduction of $\mathrm{CH}_{4}$ emissions in animals supplemented with linseed oil was of $4 \mathrm{~g}$ per kilogram of DM intake. There was therefore a reduction of $1.15 \mathrm{~g}$ of $\mathrm{CH}_{4}$ per $\mathrm{kg}$ of DM intake for every $10 \mathrm{~g}$ of supplemented lipid in the diet (linseed oil). This value corroborates the results found by Grainger and Beauchemin (2011) on a meta-analysis evaluation of the effect of different lipid sources on $\mathrm{CH}_{4}$ emission, in which they concluded that, for cattle, an increase of $10 \mathrm{~g}$ fat per $\mathrm{kg}$ of DM in diet reduces $\mathrm{CH}_{4}$ emission in $1 \mathrm{~g}$ per kilogram of DMI. The percentage reduction was of $12.6 \%$ for every $1 \%$ of lipid added. The other evaluated sources showed no reduction in the enteric $\mathrm{CH}_{4}$ emissions compared with the control diet.

Grazing animals have the potential to emit more $\mathrm{CH}_{4}$, due to the higher fiber content and acetate:propionate ratio in the rumen. Diets rich in fiber increase the lipolysis and hydrogenation rates (Jenkins, 1993), while maintain lower concentrations of UFA and, thus, decrease toxicity to microorganisms caused by the added fat (Broudiscou, 1994; Bateman and Jenkins, 1998). The inhibitory response of fats on methane production depends on concentration, type, fatty acid composition of fats, and nutrient composition of diets (Beauchemin et al., 2008). Greater concentrations of fats do substantially decrease methane production, but often 
exert detrimental effects on digestibility and fermentation of feeds including animal performance (Patra, 2013). Therefore, Chung et al. (2011) investigated the potential effects of feeding ground linseed on enteric $\mathrm{CH}_{4}$ production and showed that including ground linseed in a barley silagebased diet can mitigate enteric $\mathrm{CH}_{4}$ emissions, but not in a grass hay-based diet.

The effectiveness of linseed in reducing ruminal methanogenesis in this experiment with grazing animals is consistent with that reported in the literature on confined animals (Eugène et al., 2008; Beauchemin, et al., 2009; Martin et al., 2010), with the results reported in this work. According to Morgavi et al. (2010), the mitigation of rumen methanogenesis can be achieved by reducing the $\mathrm{H}_{2}$ supply to the methanogenics obtained from favoring the production of propionate and the methanogenic archaea and protozoa $\left(\mathrm{H}_{2}\right.$ producers). Thus, the direct action of linseed oil on microbial population was probably responsible for reduction in $\mathrm{CH}_{4}$ emission compared with animals that received no source of supplemental lipid.

Supplements rich in PUFA, such as linoleic and linolenic acids, have a mitigating effect on $\mathrm{CH}_{4}$ emission in the rumen (Martin et al., 2010). Maia et al. (2007) attributed this effect to the rupture of bacteria membrane integrity caused by unsaturation of the molecules of these fatty acids. Animals supplemented with linseed oil consumed, on average, $352 \mathrm{~g}$ of linoleic and linolenic acids every day. This represents more than double the intake of these acids in supplements without additional fat, palm, and protected fat (average of $80 \mathrm{~g} / \mathrm{d}$ ). Only the supplementation with soybean allowed intake of C18:2 and C18:3 greater than with linseed (185 g/d). Although $\mathrm{CH}_{4}$ emission was higher in animals receiving linseed oil, animals supplemented with soybeans emitted $27 \%$ less $\mathrm{CH}_{4}$ than animals that did not receive additional lipid source in the supplement.

\section{Conclusions}

The linseed oil has the potential to reduce enteric $\mathrm{CH}_{4}$ emissions in continuous tropical grazing systems based on B. brizantha grass.

\section{Acknowledgments}

The authors would like to acknowledge the State of São Paulo Research Foundation (FAPESP) for financial support (Processes numbers: 2009/06472-6; 2009/07314-5; and 2013/02408-2) and BELLMAN, a Nutreco company, for providing the lipid sources, urea, and mineral salt used in the experiment.

\section{References}

Allen, M. S. 2000. Effects of diet on short-term regulation of feed intake by lactating dairy cattle. Journal Dairy Science 83:1598-1624.

AOAC - Association of Official Analytical Chemists. 1990. Official methods of analysis. 15th ed. AOAC, Washington, DC.

Barbero, R. P.; Malheiros, E. B.; Araújo, T. L. R.; Nave, R. L. G.; Mulliniks, J. T.; Berchielli, T. T.; Ruggieri, A. C. and Reis, R. A. 2015. Combining Marandu grass grazing height and supplementation level to optimize growth and productivity of yearling bulls. Animal Feed Science and Technology 209:110-118.

Bateman II, H. G. and Jenkins, T. C. 1998. Influence of soybean oil in high fiber diets fed to nonlactating cows on ruminal unsaturated fatty acids and nutrient digestibility. Journal of Dairy Science 81:2451-2458

Beauchemin, K. A.; Kreuzer, M.; O’Mara, F. and McAllister, T. A. 2008. Nutritional management for enteric methane abatement: A review. Australian Journal of Experimental Agriculture 48:21-27.

Beauchemin, K. A.; McGinn, S. M.; Benchaar, C. and Holtshausen, L. 2009. Crushed sunflower, flax, or canola seeds in lactating dairy cow diets: Effects on methane production, rumen fermentation, and milk production. Journal of Dairy Science 92:2118-2127.

Broudiscou, L.; Pochet, S. and Poncet, C. 1994. Effect of linseed oil supplementation on feed degradation and microbial synthesis in the rumen of ciliate-free and refaunated sheep. Animal Feed Science and Technology 49:189-202.

Casali, A. O.; Detmann, E.; Valadares Filho, S. C.; Pereira, J. C.; Henriques, L. T.; Freitas, S. G. and Paulino, M. F. 2008. Influence of incubation time and particles size on indigestible compounds contents in cattle feeds and feces obtained by in situ procedures. Revista Brasileira de Zootecnia 37:335-342.

Chung, Y. H.; He, M. L.; McGinn, S. M.; McAllister, T. A. and Beauchemin, K. A. 2011. Linseed suppresses enteric methane emissions from cattle fed barley silage, but not from those fed grass hay. Animal Feed Science and Technology 166-167:321-329.

Coppock, C. E. and Wilks, D. L. 1991. Supplemental fat in high energy rations for lactating cows: Effects on intake, digestion, milk yield, and composition. Journal of Animal Science 69:3826-3837.

Doreau, M. and Chilliard, Y. 1997. Digestion and metabolism of dietary fat in farm animals. British Journal of Nutrition 78:S15-35.

Doreau, M. and Ferlay, A. 1995. Effect of dietary lipids on nitrogen metabolism in the rumen: a review. Livestock Production Science 43:97-110.

Eugène, M.; Martin, C.; Mialon, M. M.; Krauss, D.; Renand, G. and Doreau, M. 2011. Dietary linseed and starch supplementation decreases methane production of fattening bulls. Animal Feed Science and Technology 166-167:330-337.

Eugène, M.; Masse, D.; Chiquette, J. and Benchaar, C. 2008. Metaanalysis on the effects of lipid supplementation on methane production in lactating dairy cows. Canadian Journal of Animal Science 88:331-334.

Fievez, V.; Dohme, F.; Danneels, M.; Raes, K. and Demeyer, D. 2003. Fish oils as potent rumen methane inhibitors and associated effects on rumen fermentation in vitro and in vivo. Animal Feed Science and Technology 104:41-58.

Fiorentini, G.; Carvalho, I. P. C.; Messana, J. D.; Castagnino, P. S.; Berndt, A.; Canesin, R. C.; Frighetto, R. T. S. and Berchielli, T. T. 2014. Effect of lipid sources with different fatty acid profiles on the intake, performance, and methane emissions of feedlot Nellore steers. Journal of Animal Science 92:1613-1620.

Folch, J.; Lees, M. and Stanley, G. H. S. 1957. A simple method for the isolation and purification of total lipides from animal tissues. Journal of Biological Chemistry 226:497-509.

Gillis, M. H.; Duckett, S. K.; Sackmann, J. R.; Realini, C. E.; Keisler, D. H. and Pringle, T. D. 2004. Effects of supplemental rumen- 
protected conjugated linoleic acid or linoleic acid on feedlot performance, carcass quality, and leptin concentrations in beef cattle. Journal of Animal Science 82:851-859.

Goel, G.; Arvidsson, K.; Vlaeminck, B.; Bruggeman, G.; Deschepper, K. and Fievez, V. 2009. Effects of capric acid on rumen methanogenesis and biohydrogenation of linoleic and alphalinolenic acid. Animal 3:810-816.

Grainger, C. and Beauchemin, K. A. 2011. Can enteric methane emissions from ruminants be lowered without lowering their production? Animal Feed Science and Technology 166-167:308-320.

Hristov, A. N.; Oh, J.; Firkins, J. L.; Dijkstra, J.; Kebreab, E.; Waghorn, G.; Makkar, H. P. S.; Adesogan, A. T.; Yang, W.; Lee, C.; Gerber, P. J.; Henderson, B. and Tricarico, J. M. 2013. Mitigation of methane and nitrous oxide emissions from animal operations: I. A review of enteric methane mitigation options. Journal of Animal Science 91:5045-5069.

IPCC - Intergovernmental Panel on Climate Change. 2006. Chapter 3. Livestock's role in climate change and air pollution. Agriculture, forestry and other land use. 4:3.1-3.20.

Jenkins, T. C. 1993. Lipid metabolism in the rumen. Journal Dairy Science 76:3851-3863.

Johnson, K.; Huyler, M.; Westberg, H.; Lamb, B. and Zimmerman, P. 1994. Measurement of methane emissions from ruminant livestock using a sulfur hexafluoride tracer technique. Environmental Science \& Technology 28:359-362.

Kramer, J. K. C.; Fellner, V.; Dugan, M. E. R.; Sauer, F. D.; Mossoba, M. M. and Yurawecz, M. P. 1997. Evaluating acid and base catalysts in the methylation of milk and rumen fatty acids with special emphasis on conjugated dienes and total trans fatty acids. Lipids 32:1219-1228.

Kurihara, M.; Magner, T.; Hunter, R. A. and McCrabb, G. J. 1999. Methane production and energy partition of cattle in the tropics. British Journal of Nutrition 81:227-34.

Lanna, D. P. D.; Barioni, L. G.; Boin, C. and Tedeschi, L. O. 1999. RLM 2.0 - Feed for maximum profit, version 2.0. Piracicaba, SP, Brazil.

Ludden, P. A.; Kucuk, O.; Rule, D. C. and Hess, B. W. 2009. Growth and carcass fatty acid composition of beef steers fed soybean oil for increasing duration before slaughter. Meat Science 82:185-192.

Machmüller, A.; Ossowski, D. A.; Wanner, M. and Kreuzer, M. 1998. Potential of various fatty feeds to reduce methane release from rumen fermentation in vitro (Rusitec). Animal Feed Science and Technology 71:117-130.

Maia, M. R.; Chaudhary, L. C.; Figueres, L. and Wallace, R. J. 2007. Metabolism of polyunsaturated fatty acids and their toxicity to the microflora of the rumen. Antonie Van Leeuwenhoek 91:303-314.

Manso, T.; Castro, T.; Mantecón, A. R. and Jimeno, V. 2006. Effects of palm oil and calcium soaps of palm oil fatty acids in fattening diets on digestibility, performance and chemical body composition of lambs. Animal Feed Science and Technology 127:175-186.

Martin, C.; Morgavi, D. P. and Doreau, M. 2010. Methane mitigation in ruminants: from microbe to the farm scale. Animal 4:351-365.
Martin, C.; Rouel, J.; Jouany, J. P.; Doreau, M. and Chilliard, Y. 2008. Methane output and diet digestibility in response to feeding dairy cows crude linseed, extruded linseed, or linseed oil. Journal of Animal Science 86:2642-2650.

Mertens, D. R. 2002. Gravimetric determination of amylase-treated neutral detergent fiber in feeds with refluxing in beakers or crucibles: collaborative study. Journal of AOAC International $85: 1217-1240$

Morgavi, D. P.; Forano, E.; Martin, C. and Newbold, C. J. 2010 Microbial ecosystem and methanogenesis in ruminants. Animal 4:1024-1036.

Nelson, M. L.; Marks, D. J.; Busboom, J. R.; Cronrath, J. D. and Falen, L. 2004. Effects of supplemental fat on growth performance and quality of beef from steers fed barley-potato product finishing diets: I. Feedlot performance, carcass traits, appearance, water binding, retail storage, and palatability attributes. Journal of Animal Science 82:3600-3610.

Neto, A. J.; Messana, J. D.; Ribeiro, A. F.; Vito, E. S.; Rossi, L. G. and Berchielli, T. T. 2015. Effect of starch-based supplementation level combined with oil on intake, performance, and methane emissions of growing Nellore bulls on pasture. Journal of Animal Science 93:2275-2284.

Patra, A. K. 2013. The effect of dietary fats on methane emissions, and its other effects on digestibility, rumen fermentation and lactation performance in cattle: A meta-analysis. Livestock Science 155:244-254.

Pelve, M. E.; Olsson, I.; Spörndly, E. and Eriksson, T. 2012. In vivo and in vitro digestibility, nitrogen balance and methane production in non-lactating cows and heifers fed forage harvested from heterogeneous semi-natural pastures. Livestock Science 144:48-56.

Rosa, B. L.; Sampaio, A. A. M.; Henrique, W.; Oliveira. E. A. D.; Pivaro, T. M.; Andrade, A. T. D. and Fernandes, A. R. M. 2013. Performance and carcass characteristics of Nellore young bulls fed different sources of oils, protected or not from rumen degradation. Revista Brasileira de Zootecnia 42:109-116.

Santos, S. A.; Valadares Filho, S. C.; Detmann, E.; Valadares, R. F. D.; Ruas, J. R. M. and Amaral, P. M. 2011. Different forage sources for F1 Holstein $\times$ Gir dairy cows. Livestock Science 142:48-58.

Soliva, C. R.; Meile, L.; Cieslak, A.; Kreuzer, M. and Machmüller, A. 2004b. Rumen simulation technique study on the interactions of dietary lauric and myristic acid supplementation in suppressing ruminal methanogenesis. British Journal of Nutrition 92:689-700.

Soliva, C. R.; Meile, L.; Hindrichsen, I. K.; Kreuzer, M. and Machmüller, A. 2004a. Myristic acid supports the immediate inhibitory effect of lauric acid on ruminal methanogens and methane release. Anaerobe 10:269-276.

Van Soest, P. J.; Robertson, J. B. and Lewis, B. A. 1991. Methods for dietary fiber, neutral detergent fiber, and nonstarch polysaccharides in relation to animal nutrition. Journal of Dairy Science 74:3583-3597.

Wanapat, M.; Mapato, C.; Pilajun, R. and Toburan, W. 2011. Effects of vegetable oil supplementation on feed intake, rumen fermentation, growth performance, and carcass characteristic of growing swamp buffaloes. Livestock Science 135:32-37. 